\title{
The Importance of Arts Education: Graduation and Dropout Rates at a School of Music in the Bronx, New York (2007-2011)
}

\author{
By Nicolás Alberto Dosman*
}

\begin{abstract}
Arts education as a part of the curriculum is not viewed as a priority by many government leaders. During the Global Recession in 2007, arts education programs in the United States and around the world may have been eliminated. As the world-wide economy recovered, some arts education programs may have been reconstituted. However, arts education programs in less affluent communities, may not be valued by civic leaders. Although the U.S. and world economy are relatively stable, there are indicators that a recession may be approaching. This paper discusses the graduation rates and dropout rates of the Celia Cruz High School of Music in comparison to other public schools in the Bronx, the City of New York public school system, and other arts focused schools during the height of the Great Recession. The data during this time period indicate that Celia Cruz High School Music had consistently higher graduation rates and lower dropout rates in comparison to the average of the city of New York and the Bronx schools during this period. The case can be made that arts education is a fundamental part of one's education and the arts can be a vehicle to assist socioeconomically challenged students realize their potential. Arts education programs may be perceived as an "extra" or non-essential in many parts of the world. Even when arts education is valued as a part of the educational system, it is often reserved for those that have the means to afford it. Communities around the world as well as world leaders should consider the importance of arts education, particularly in communities that experience socioeconomic challenges. Existing data can make a compelling case for continuing arts education programs especially in less affluent communities.
\end{abstract}

\section{Introduction}

Music education and the arts in general have been under scrutiny for many years in the United States. In economically challenged urban areas, the arts are generally a low priority and sometimes minimally included or absent from the school curriculum ${ }^{1}$. Socioeconomically challenged areas could have music schools or schools with an arts focus, while the surrounding schools which are generally comprehensive may not be able to provide any arts or music instruction even if

"Assistant Professor of Music, University of Southern Maine, USA.

1. James Rohner, "Rally The Troops," The Instrumentalist, 2010 
administrators value the arts ${ }^{2}$. The absence of music programs may affect schools that do not have the financial resources to support these programs in large urban areas, even when the national economy is relatively healthy.

The data presented in this paper was at the beginning of the recovery period of the Great Recession. Prior to the Great Recession, subjects that were tested were valued because of the federal funding associated with these subjects. Student performance in these subject areas affected the level of federal funding and even state funding in some cases. Because of this connection to federal funding, schools in urban areas may have experienced a reduction or even long-term elimination of arts and music programs ${ }^{3}$. In some cases, enrichment courses replaced arts courses and other electives for students. However, broad elimination of arts programs, fail to recognize that schools in socioeconomically challenged areas may be able to showcase an arts-intensive school in their neighborhood and possibly demonstrate that the arts enhance student performance on multiple levels. This argument may speak volumes to lawmakers, even during turbulent economic times.

The state of the U.S. economy in 2019 is stable and has since recovered from the Great Recession. However, according to some economists (Moore, 2019), there are economic warning signs that indicate that a recession may be looming ahead ${ }^{4}$. The signs that are cited for a future recession are as follows: the yield curve inversion in 2019 - the inversion is becoming deeper and broader (models based on the current yield curve indicate a $30-40 \%$ chance of hitting a recession in a year), global growth is slowing, talk of recession has been increasing; and although unemployment is currently low in the U.S. (3.7\% as of July 2019), if there is an increase of $0.5 \%$ to $4.1 \%$ this could be yet another indicator of a recession Additionally, trade wars and other global events may have an effect on the U.S. and global economy.

The Trump administration has not enacted any new educational laws. The last law to have passed Congress with respect to education, was Every Student Succeeds Act (ESSA) (passed on December 10, 2015 and signed by President Obama). President Obama's education agenda was targeted at improving schools in impoverished areas, but the focus was primarily on tested subjects like science and mathematics. Although impoverished areas may benefit from increased funding at the federal level to address the academic performance of their student body, they may still need to contend with budget shortfalls at the local and state

2. Carlos R. Abril and Brent M. Gault, "The State of Music in the Elementary School: The Principals Perspective," Journal of Research in Music Education 54, no. 1 (2006): 6, https:// doi.org/10.2307/3653452.

3. David E. Gullatt, "Research Links the Arts with Student Academic Gains," The Educational Forum 71, no. 3 (2007): 211-220, https://doi.org/10.1080/00131720709335006

4. Simon Moore, "What Key Recession Indicators Are Telling Us Today," Forbes Forbes Magazine, August 20, 2019, https://bit.ly/2YMnGMH. 
levels. Budget shortfalls in impoverished areas may lead to further cuts in the arts, particularly in urban areas that underperform academically. However, arts programs, especially magnet schools or talent academies in low-income or schools that are considered to be academically failing, have documented success in the form of increased graduation rates (tied to state testing) as well as increased

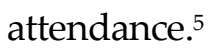

In the U.S., both educational funding and school prestige are linked to tested subjects. Such academic subjects can show measurable student progress which may be valued by politicians and school principals alike. However, music education and arts education are in jeopardy because of this lack of a tie to testing. Urban areas may not have the funding to continue programs, particularly if they are experiencing an economic downturn and funding for these programs may no longer be available at local, state, and federal levels. Conversely, state and federal funding are generally directed towards tested subjects.

The heart of this research revolved around the Celia Cruz Bronx High School, a musically focused high school, which was created for the purpose of allowing students to realize their artistic and academic potential. The musical and artistic nature of the school is the primary focus of the institution which may in and of itself enrich the lives of the students it serves; this philosophy may fit well with some ideology within the profession. However, decision-makers such as superintendents and politicians may be swayed by other arguments. For example, President Obama acknowledged in his 2011 State of the Union address that America must continue to be creative and innovative. Despite this apparent nod to creativity which could be construed as inclusive of the arts, the Obama administration's educational agenda focused on STEM (Science, Technology, Engineering, and Math) initiatives. STEM appears to exclude the arts as well as the potential that schools like Celia Cruz in the Bronx and similar schools around the nation that were specifically created to nurture and foster artistic creativity in their students ${ }^{6}$.

The Common Core Standards, another educational initiative under the Obama administration, is focused on academic performance in English/Language Arts and Mathematics. STEM and the Common Core Standards may have goals in improving the performance of students in American public schools but the arts are noticeably excluded from these initiatives. The goals in federally mandated initiative such as STEM or the Common Core Standards may be to better prepare graduates for the workforce and college, assuming that they will remain in school to complete their education. However, it is does not address the fact many students do not complete their education particularly in urban schools. If these

5. James J. Kemple, Corrine Herlihy, and Thomas J Smith, "Making Progress Toward Graduation," MDRC, April 24, 2017, https://bit.ly/2N5FQnl.

6. Diane C. Dawood, "College Readiness and Academic Success for Arts Magnet and Traditional High School Graduates" (dissertation, 2009). 
programs are to be effective in socioeconomically challenged areas, it is essential that students remain in school and ultimately complete their high school education particularly in areas where dropouts are higher than the national average. The federal initiatives under President Obama may have been well intentioned; the narrow focus of these programs may need to be reexamined especially when urban schools with limited resources are being scrutinized and assessed.

\section{Literature Review and Political Climate in the United States}

The Trump administration has not passed any new legislation with respect to arts education or education in general. However, there may be signs that the arts and potentially arts education may be at risk. According to The Washington Post ${ }^{7}$, the Trump administration's 2020 budget plans to severely cut or eliminate the National Endowment for the Arts (NEA) and the National Endowment for the Humanities (NEH). Moreover, it appears as though the administration's FY 2017 and FY 2018 budget proposals called for an elimination of the NEA. Despite the efforts of the current administration to undermine arts organizations like the NEA, both the NEA and NEH still exist. Additionally, it appears as though the Trump administration plans to cut funding for the Department of Education. The administration's FY 2019 budget proposal was $\$ 59.9$ billion, a $\$ 7.1$ billion decrease from 2017. This action, during strong economic growth in the U.S. may be a strong indication of the administration's priorities ${ }^{8}$. Although the administration's budget proposal decreases funding for the Department of Education, it appears to prioritize STEM “The Budget supports STEM education through a variety of programs including those that test and replicate what works in education and a new, \$20 million grant program for STEM-focused career and technical education programs (p. 43)".

Some have suggested that the lawmakers change their focus from STEM and similar initiatives, to STEAM (Science, Technology, Engineering, Arts, and Math) 9 . This change would be inclusive of the arts as well as serve the goals of creativity and innovation that the Obama administration espoused. The case for STEAM is based on the premise that cutting or eliminating the arts from the national curriculum will limit the creative potential of future generations. Proponents of STEAM refer to China as having this model. According to White, all teaching programs in China have included courses in music and fine art, featuring singing,

7. Peggy McGlone, "For Third Year in a Row, Trump's Budget Plan Eliminates Arts, Public TV and Library Funding," Washington Post, March 18, 2019.

8. U.S. Office of Management and Budget (2019). Budget of the U.S. Government Fiscal Year 2019. Retrieved from https://bit.ly/3hGCmFZ.

9. White, Harvey, “White Paper: STEAM Not STEM," n.d. 
musical knowledge and appreciation, painting, arts and crafts, and appreciation of fine arts in their contents. Although STEAM proponents may make valid arguments in favor of arts education, other arguments such as a decrease in dropout rates and increase in graduation rates in socioeconomically-deprived areas like the Bronx may be equally valid. Based on the cuts to the NEA, NEH, and Department of Education the current administration may not be as open to STEAM despite evidence of its success.

During the period known as the Great Recession in the United States, the Bronx was the poorest borough in New York City, with the highest rate of poverty as well as a higher poverty rate than the national average. According to the U.S. Census ${ }^{10}$, the majority of the population in the Bronx at that time was $53.8 \%$ Hispanic, $11.2 \%$ White non-Hispanic, and $43.3 \%$ Black; $29 \%$ are foreign-born as opposed to $11.1 \%$ nationwide, and $52.7 \%$ speak a language other than English at home in contrast to $17.9 \%$ nationwide. Moreover, $27.3 \%$ of the Bronx population were living below the poverty line, as opposed to $13.7 \%$ in New York City and $13.2 \%$ in the United States. The 2011 estimate of the percentage of persons in the Bronx over the age of 25 holding a high school diploma or higher was $62.9 \%$, in New York City $84.6 \%$, and nationwide $85.4 \%$. These data indicate that the economic conditions of residents in the Bronx were worse and the educational attainment was lower than in the city and the national average. The socioeconomic conditions and poverty level of the Bronx demonstrate that students in this borough may have been social-emotionally, socioeconomically, or academically deprived. If one were to base the future of high school graduates from the Bronx on past Census results, their likelihood of graduation compared to New York City and the nation is lower based on the percentage of high school graduates over the age of 25 ().

In the latest census estimate ${ }^{11}$ the three largest ethnic/racial groups in the Bronx were 56.4\% Hispanic, 9.1\% 43.6\% Black and White non-Hispanic (no significant statistical shift from 2011) 35.3\% are foreign born (statistically significant change from 2011) and 59.3\% speak a language other than English at home. The population of the Bronx over the age of 25 holding a high school diploma or higher was $71.5 \%$ (statistically significant change from 2011). The poverty rate was estimated to be at $27.9 \%$ (no statistically significant change). Most of the conditions of the Bronx have remained relatively the same from 2011 with the exception of the foreign-born population and educational attainment (both higher).

At the time of Celia Cruz's creation, over half of the high schools in the Bronx had failed to meet state standards, and educational leaders were looking for

10. “U.S. Census Bureau QuickFacts: United States.” Census Bureau QuickFacts, accessed April 4, 2020, https://bit.ly/2CjEwLr.

11. U.S. Census Bureau QuickFacts: Bronx County (Bronx Borough), New York," Census Bureau QuickFacts, accessed April 4, 2020, https://bit.ly/37GFfSu. 
solutions to address this problem. Many larger schools in the New York City area were being revamped into several smaller schools within a building where a larger comprehensive school had previously existed in order to better service their students. This movement at the time was a popular trend and was anticipated as becoming the educational norm in New York City and other large urban districts. Small schools had the support of the Bill and Melinda Gates Foundation which also funded similar initiatives in Chicago ${ }^{12}$ (p. 12). These schools would not be designed to merely mirror large schools with a reduced population, but rather to significantly change teaching and learning as well as improve graduation rates (p. 35). Smaller schools appeared to be more successful than larger schools and offered more intimate contact among school personnel, students, and parents. However, these schools did not address the needs of students who wanted to focus on a musically intensive curriculum throughout their high school career.

Dr. William Rodriguez successfully included a proposal to include a high school of music, created as a small school. Celia Cruz became part of the small school movement under the Bronx New Century High School Initiative and was the means of offering students in the Bronx a musically intensive community while retaining the tenets of the small school movement. Rodriguez conducted a qualitative study which documented the journey of Celia Cruz High School from its inception. He found that the Bronx needed a school of music, according to the voices of the community, parents, educators, and students. Although New York City had many schools of music and the arts, Rodriguez found that many parents and students would never audition for schools that were not in their borough; this became another rationale to support the creation of Celia Cruz High School (p. 133).

Studies of talent-focused schools, particularly in poor urban areas, have yielded positive results. For example, one key finding of the MDRC (formerly Manpower Demonstration Research Corporation) report ${ }^{13}$, were that graduation rates and attendance rates had improved dramatically as a result of high schoolaged youth participating in a talent academy in an urban setting . Conversely, other studies suggest that all students regardless of their setting may benefit from arts education ${ }^{14}$. Similar studies indicate that instrumental experiences help

12. William Rodriguez, "Creating a School of Music: a Bronx New Century High School Initiative" (dissertation, 2003)

13. James J Kemple, Corrine Herlihy, and Thomas J Smith, "Making Progress Towards Graduation: Evidence from the Talent Development High School Model," (Manpower Demonstration Research Corporation, May 1, 2005), https://bit.ly/2AFwJqW.

14. Harold Abeles, Judith Burton, and Robert Horowitz (Center for Arts Education Research Teachers College, Columbia University, July 1, 1999), https://bit.ly/2UTbj04 
students develop self-regulation ${ }^{15}$. Research also suggests that music may help students' self-regulation, but is not limited exclusively to instrumental music. In his research, Freer found that self-regulation can also be experienced in a vocal or choral setting ${ }^{16}$. The ability to self-regulate and make informed choices for oneself is a transferable life skill that can benefit students in a range of disciplines. All of these studies suggest that regardless of genre of music education, setting or discipline, music education clearly appears to benefit students. Skills such as selfregulation are important for all students, particularly those who lack stability in their lives because of socioeconomic hardships. In short, research supports the idea that arts enrichment may advance educational outcomes for at-risk children regardless of race and ethnicity ${ }^{17}$. Schools like Celia Cruz High School were created for this purpose (p. 117).

Despite convincing evidence of the relationship between students participating in music classes and higher academic performance and social adjustment, music programs continue to struggle for their place in the curriculum ${ }^{18}$. Therefore, further research may help build a stronger case for music education, particularly in urban settings that have limited funding and may be underperforming as defined by state testing criteria. Celia Cruz High School in the Bronx was examined to determine if a school with a musical focus would yield higher graduation rates and lower dropout rates than other schools in the same borough and city.

The purpose of this investigation was to compare their graduation rates and dropout rates of students enrolled in Celia Cruz with similar schools in the New York City public system as well as to make comparisons between this school and its borough and the New York City public school system as a whole. To address these issues, data collected from the New York City Department of Education that included graduation rates and dropout rates were analyzed over a five-year period. Additionally, data comparing this school with the state of New York average was to give a broader comparison between the school, the district, and the entire state that includes other urban communities, suburban communities, and even rural communities. Because this study is non-experimental in nature, it

15. Barry Oreck, Susan Baum, and Heather McCartney, "Champions of Change: The Impact of the Arts on Learning," (National Research Center on the Gifted and Talented University of Connecticut, Storrs, 1999), https://bit.ly/3dhh6CZ.

16. Patrick K. Freer, "Boys' Descriptions of Their Experiences in Choral Music," Research Studies in Music Education 31, no. 2 (December 1, 2009):. 142-160, https://doi.org/ 10.1177/1321103X09344382.

17. Eleanor D Brown, Barbara Benedett, and M. Elizabeth Armistead, "Arts Enrichment and School Readiness for Children at Risk," Early Childhood Research Quarterly 25, no. 1 (2010): 112-124, http://dx.doi.org/10.1016/j.ecresq.2009.07.008.

18. Cecil Adderley, Mary Kennedy, and William Berz, "A Home Away from Home': The World of the High School Music Classroom," Journal of Research in Music Education 51, no. 3 (October 1, 2003): 190-205, https://doi.org/10.2307/3345373 
is designed to highlight existing data rather than generate new data. The data in this study is designed to highlight facts about Celia Cruz high school and its history of academic performance.

The conceptual framework behind this study acknowledges that family background, language and cultural diversity, poverty, crime, drug-ridden neighborhoods, and single-parent, mostly female-headed households may determine the opportunity to learn, but not the capacity for learning ${ }^{19}$. In framing the parameters of this investigation, the researcher is working under the perception that some schools in urban areas may view eliminating arts programs instead of more academic programs as a solution to the problems that some urban schools face with low test scores and limited funding. However, studies show that students in grades 8-12 who are highly involved in the arts and come from low socioeconomic backgrounds have higher grades, perform better on standardized tests, and are less likely to drop out of school by the tenth grade. Arts enrichment may also advance educational outcomes for children at risk, regardless of race and ethnicity. Finally, Celia Cruz was chosen because of its exclusive focus on music and its unique circumstance; their admission criteria is based on musical ability and does not account for academic performance. Celia Cruz High School was created as a school of music to advance the educational outcomes of students from the Bronx who may have socioeconomic limitations. Although many students enter schools with a given family background and history, music programs can influence the students and may be a factor that motivates them to stay in school and subsequently graduate from high school despite any economic or social limitations.

\section{Research Questions}

1. What was the graduation rate of Celia Cruz in comparison to other schools in the Bronx?

2. How did the dropout rate compare to other schools in the Bronx?

3. How did Celia Cruz graduation rates compare to other schools in the City of New York?

4. How did Celia Cruz dropout rates compare to other schools in the City of New York?

19. Beverly E Cross, "Urban School Achievement Gap as a Metaphor to Conceal U.S. Apartheid Education," Theory into Practice 46, no. 3 (October 31, 2010): 247-255, https://doi. org/10.1080/00405840701402299. 


\section{Methodology}

Non-experimental statistical data available from the New York City Department of Education were used to present the graduation rates and dropout rates of Celia Cruz High School. The quantitative data presented in this study are ex post facto data, that is, information on the academic performance of Celia Cruz High School as compared with other schools in the New York City Public School System.

Comparisons were made across and within data samples. Data specifically regarding graduation rates and dropout rates were compared for students in their borough, district, and similar schools. Graduation data were compared on a Graduate/Non-Graduate basis based on a four-year cohort. Performance on standardized test scores were not taken into consideration to make similar comparisons. The data from Celia Cruz students were compared with borough, district, and state averages.

\section{Results - Comparisons within the Bronx, New York City and New York State}

The following numbers compare Celia Cruz High School graduation rates with the borough of the Bronx as well as the overall graduation rate of New York City.

For graduation rates of Celia Cruz High School:

$$
\begin{aligned}
& \text { 2006-2007: } \mathrm{n}=76 \text { and grads }=60 \\
& \text { 2007-2008: } \mathrm{n}=72 \text { and grads }=42 \\
& \text { 2008-2009: } \mathrm{n}=74 \text { and grads }=50 \\
& 2009-2010: \mathrm{n}=82 \text { and grads }=61 \\
& 2010-2011: \mathrm{n}=85 \text { and grads }=60
\end{aligned}
$$

For the borough of the Bronx

2006-2007: $\mathrm{n}=13,632$ and grads $=6,389$

2007-2008: $\mathrm{n}=14,364$ and grads $=7,448$

2008-2009: $\mathrm{n}=15,175$ and grads $=8,229$

2009-2010: $\mathrm{n}=15,579$ and grads $=8,524$

2010-2011: $\mathrm{n}=15,987$ and grads $=8,421$

For New York City graduation rates:

2006-2007: $\mathrm{n}=73,888$ and grads $=38,990$

2007-2008: $\mathrm{n}=75,009$ and grads $=42,313$

2008-2009: $\mathrm{n}=77,378$ and grads $=45,615$

2009-2010: $\mathrm{n}=78,346$ and grads $=47,786$

2010-2011: $\mathrm{n}=79,476$ and grads $=48,380$ 
The graduation rates below are based on cohorts that graduated within four years in the month of June Table 1 shows a five-year average comparing Celia Cruz High School, the Bronx, and the New York City Public school system. ${ }^{20}$ Celia Cruz consistently had higher graduation rates than the Bronx by a considerable margin over a five-year period. Additionally, Celia Cruz High School's graduation has been consistently higher than the New York City public school average during this period. Although the gap between Celia Cruz High School and New York City schools had been very wide in some years, particularly in 2007 and 2010, the gap had not been as wide as that of the Bronx borough average. In 2008, the graduation rates of Celia Cruz, the Bronx, and New York City were low across the board and the graduation rates in this particular year were most similar.

Table 1. Graduation Rates Percentages-Celia Cruz High School, Bronx Borough, New York City

\begin{tabular}{|l|c|c|c|c|c|}
\cline { 2 - 5 } \multicolumn{1}{c|}{} & $\mathbf{2 0 0 7}$ & $\mathbf{2 0 0 8}$ & $\mathbf{2 0 0 9}$ & $\mathbf{2 0 1 0}$ & $\mathbf{2 0 1 1}$ \\
\hline Celia Cruz High School & $78.9 \%$ & $58.3 \%$ & $67.6 \%$ & $74.4 \%$ & $70.6 \%$ \\
\hline Bronx Borough Average & $46.9 \%$ & $51.9 \%$ & $54.2 \%$ & $54.7 \%$ & $52.7 \%$ \\
\hline New York City Public School Average & $52.8 \%$ & $56.4 \%$ & $59 \%$ & $61 \%$ & $60.9 \%$ \\
\hline
\end{tabular}

Table 2 shows a 4-year average comparing Celia Cruz High School, the state of New York, and the New York City Public school system. Celia Cruz had lower graduation rates than the state of New York, the graduation rates of students increased over time to match state averages over time. Additionally, Celia Cruz High School's graduation had been consistently higher than the New York City public school average for the last four years. Although the gap between Celia Cruz High School and New York City schools has been very wide in some years, particularly and 2010, the gap had not been as wide as that of the Bronx borough average. In 2008, the graduation rates of Celia Cruz High School and New York City were low. The graduation rates in this particular year were most similar between city of New York and Celia Cruz. However, the differences between the city of New York, Celia Cruz High School and the state of New York were the greatest.

Table 2. Celia Cruz, New York State, New York City Graduation Rates 2008-2011

\begin{tabular}{|l|c|c|c|c|}
\cline { 2 - 5 } \multicolumn{1}{c|}{} & $\mathbf{2 0 0 8}$ & $\mathbf{2 0 0 9}$ & $\mathbf{2 0 1 0}$ & $\mathbf{2 0 1 1}$ \\
\hline Celia Cruz High School & $58.3 \%$ & $67.6 \%$ & $74.4 \%$ & $70.6 \%$ \\
\hline New York State Average & $71.0 \%$ & $74.0 \%$ & $76.0 \%$ & $74.0 \%$ \\
\hline New York City Average & $56.4 \%$ & $59.0 \%$ & $61.0 \%$ & $60.9 \%$ \\
\hline
\end{tabular}

20. "Cohorts of 2001 through 2007(Classes 2005-2011) Graduation Outcomes," Cohorts of 2001 through 2007 (classes 2005-2011) Graduation outcomes § (n.d.), https://on.nyc.gov/2 BipvJm. 
Graduation rates were compared over a 3-year period between Celia Cruz and all specialized schools in the Bronx. Tables 3, 4, and 5 respectively, show the graduation rate of Celia Cruz High School compared to all schools of the Bronx in the New York City public school system from 2009-2011. Celia Cruz's graduation rate was most similar to many of the arts schools in the Bronx and Brooklyn. However, the graduation rate of Celia Cruz high school was lower than the average of tall of the arts schools in the New York City public school system. In general, the arts schools within the New York City public school system had higher graduation rates when compared with the average of all public schools in New York City

Table 3. Graduation Rates 2009-Celia Cruz, New York City Schools of Arts, Borough

\begin{tabular}{|c|c|c|c|c|c|}
\hline Bronx & Year & June & $\mathbf{N}$ & Grads & $\%$ \\
\hline Celia Cruz High School & 2009 & 4 Year & 74 & 50 & 67.6 \\
\hline Fordham High School of the Arts & 2009 & 4 Year & 89 & 63 & 70.8 \\
\hline \multicolumn{6}{|l|}{ Brooklyn } \\
\hline Brooklyn High School of the Arts & 2009 & 4 Year & 154 & 106 & 68.8 \\
\hline Brooklyn School for Music \& Theatre & 2009 & 4 Year & 98 & 80 & 81.6 \\
\hline Dr. Susan McKinney High School & 2009 & 4 Year & 100 & 46 & 46.0 \\
\hline Edward R. Murrow High School & 2009 & 4 Year & 879 & 611 & 69.5 \\
\hline Forth Hamilton High School & 2009 & 4 Year & 1,044 & 628 & 60.2 \\
\hline Juan Morel Campos Secondary School & 2009 & 4 Year & 94 & 46 & 48.9 \\
\hline \multicolumn{6}{|l|}{ Manhattan } \\
\hline Choir Academy of Harlem & 2009 & 4 Year & 84 & 47 & 56.0 \\
\hline F.H. LaGuardia High School of Music & 2009 & 4 Year & 655 & 631 & 96.3 \\
\hline Professional Performing Arts High School & 2009 & 4 Year & 100 & 95 & 95.0 \\
\hline Talent Unlimited High School & 2009 & 4 Year & 92 & 82 & 89.1 \\
\hline Wadleigh School for the Performing Arts & 2009 & 4 Year & 128 & 90 & 70.3 \\
\hline Gramercy Arts High School & 2009 & 4 Year & 68 & 50 & 73.5 \\
\hline \multicolumn{6}{|l|}{ Queens } \\
\hline Bayside High School & 2009 & 4 Year & 1,085 & 854 & 78.7 \\
\hline Forest Hills High School & 2009 & 4 Year & 946 & 758 & 80.1 \\
\hline Frank Sinatra School of the Arts & 2009 & 4 Year & 162 & 156 & 96.3 \\
\hline Humanities and Arts Magnet School & 2009 & 4 Year & 107 & 82 & 76.6 \\
\hline \multicolumn{6}{|l|}{ Staten Island } \\
\hline Susan Wagner High School & 2009 & 4 Year & 865 & 605 & 69.9 \\
\hline TOTAL ALL BOROUGHS & 2009 & 4 year & 6,824 & 5,080 & 74.4 \\
\hline
\end{tabular}

Table 4. Graduation Rates 2010 -Celia Cruz, New York City Schools of Arts by Borough

\begin{tabular}{|l|c|c|c|c|c|}
\hline Bronx & Year & June & N & Grads & $\%$ \\
\hline Celia Cruz High School & 2010 & 4 Year & 82 & 61 & 74.4 \\
\hline Fordham High School of the Arts & 2010 & 4 Year & 82 & 60 & 73.2 \\
\hline Brooklyn & & & & & \\
\hline Brooklyn High School of the Arts & 2010 & 4 Year & 100 & 72 & 72.0 \\
\hline Brooklyn School for Music and Theatre & 2010 & 4 Year & 88 & 65 & 73.9 \\
\hline
\end{tabular}




\begin{tabular}{|l|c|c|c|c|c|} 
Dr. Susan McKinney School of the Arts & 2010 & 4 Year & 81 & 66 & 81.5 \\
\hline Edward R. Murrow High School & 2010 & 4 Year & 938 & 702 & 74.8 \\
\hline Fort Hamilton High School & 2010 & 4 Year & 986 & 650 & 65.9 \\
\hline Juan Morel Campos Secondary School & 2010 & 4 Year & 100 & 40 & 40.0 \\
\hline Manhattan & & & & & \\
\hline Choir Academy of Harlem & 2010 & 4 Year & 39 & 22 & 56.4 \\
\hline F. LaGuardia High School of Music & 2010 & 4 Year & 646 & 627 & 97.1 \\
\hline Professional Performing Arts High School & 2010 & 4 Year & 80 & 74 & 92.3 \\
\hline Talent Unlimited High School & 2010 & 4 Year & 136 & 126 & 92.6 \\
\hline Wadleigh School for the Performing Arts & 2010 & 4 Year & 127 & 71 & 55.9 \\
\hline Gramercy Arts High School & 2010 & 4 Year & 93 & 68 & 73.1 \\
\hline Queens & & & & & \\
\hline Bayside High School & 2010 & 4 Year & 902 & 723 & 80.2 \\
\hline Forest Hills High School & 2010 & 4 Year & 959 & 811 & 84.6 \\
\hline Frank Sinatra School of the Arts & 2010 & 4 Year & 171 & 162 & 94.7 \\
\hline Humanities and Arts Magnet High School & 2010 & 4 Year & 94 & 72 & 76.6 \\
\hline Staten Island & & & & & \\
\hline Susan E. Wagner High School & 2010 & 4 Year & 912 & 692 & 75.9 \\
\hline All Combined Boroughs Total & 2010 & 4 Year & 6,616 & 5,164 & 78.1 \\
\hline
\end{tabular}

Table 5. Graduation Rates 2011-Celia Cruz, New York City Schools of Arts by Borough

\begin{tabular}{|c|c|c|c|c|c|}
\hline Bronx & Year & June & $\mathbf{N}$ & Grads & $\%$ \\
\hline Celia Cruz High School & 2011 & 4 Year & 85 & 60 & 70.1 \\
\hline Fordham High School of the Arts & 2011 & 4 Year & 69 & 57 & 82.6 \\
\hline \multicolumn{6}{|l|}{ Brooklyn } \\
\hline Brooklyn High School of the Arts & 2011 & 4 Year & 96 & 78 & 82.3 \\
\hline Brooklyn School for Music and Theater & 2011 & 4 Year & 88 & 60 & 68.2 \\
\hline $\begin{array}{l}\text { Dr. Susan S. McKinney Secondary School of } \\
\text { the Arts }\end{array}$ & 2011 & 4 Year & 72 & 56 & 77.8 \\
\hline Edward R. Murrow High School & 2011 & 4 Year & 987 & 710 & 71.9 \\
\hline Fort Hamilton High School & 2011 & 4 Year & 1,144 & 740 & 64.7 \\
\hline Juan Morel Campos Secondary School & 2011 & 4 Year & 99 & 40 & 40.4 \\
\hline \multicolumn{6}{|l|}{ Manhattan } \\
\hline Choir Academy of Harlem & 2011 & 4 Year & 45 & 30 & 66.7 \\
\hline $\begin{array}{l}\text { Fiorello H. LaGuardia High School of } \\
\text { Music }\end{array}$ & 2011 & 4 Year & 601 & 586 & 97.5 \\
\hline Professional Performing Arts High School & 2011 & 4 Year & 100 & 90 & 90 \\
\hline Talent Unlimited High School & 2011 & 4 Year & 85 & 79 & 92.9 \\
\hline $\begin{array}{l}\text { Wadleigh Secondary School for the } \\
\text { Performing Arts }\end{array}$ & 2011 & 4 Year & 122 & 73 & 59.8 \\
\hline Gramercy Arts High School & 2011 & 4 Year & 72 & 53 & 73.6 \\
\hline \multicolumn{6}{|l|}{ Queens } \\
\hline Bayside High School & 2011 & 4 Year & 972 & 811 & 83.4 \\
\hline Forest Hills High School & 2011 & 4 Year & 1,027 & 840 & 81.8 \\
\hline $\begin{array}{l}\text { Frank Sinatra School of the Arts High } \\
\text { School }\end{array}$ & 2011 & 4 Year & 138 & 123 & 89.1 \\
\hline Humanities and Arts Magnet High School & 2011 & 4 Year & 107 & 77 & 72.0 \\
\hline \multicolumn{6}{|l|}{ Staten Island } \\
\hline Susan E. Wagner High School & 2011 & 4 Year & 761 & 603 & 79.2 \\
\hline All Boroughs Totals & 2011 & 4 Year & 6,670 & 5,166 & $77 . .5$ \\
\hline
\end{tabular}


Table 6 compares the dropout rates of Celia Cruz and all schools of the arts that require an audition for admission in New York City over a three-year period. Celia Cruz's dropout rate was similar to most schools of the arts. Table 7 shows the dropout rates of Celia Cruz, the Bronx, and New York City public schools over that same period. Celia Cruz's dropout rates are much lower than the city and borough throughout all three years.

Table 6. Dropout Rates-Celia Cruz, All Arts Schools New York City Public Schools 2009-2011

\begin{tabular}{|c|c|c|c|}
\hline Bronx & $2009 \%$ & $2010 \%$ & $2011 \%$ \\
\hline Celia Cruz High School & 2.7 & 2.7 & 2.7 \\
\hline Fordham High School of the Arts & 3.0 & 1.0 & 1.0 \\
\hline \multicolumn{4}{|l|}{ Brooklyn } \\
\hline Brooklyn High School of the Arts & 2.0 & 1.0 & 2.0 \\
\hline Brooklyn School for Music and Theatre & 1.0 & 3.0 & 4.0 \\
\hline Dr. Susan McKinney Secondary SOTA & 2.0 & 4.0 & 2.0 \\
\hline Edward R. Murrow High School & 2.0 & 3.0 & 3.0 \\
\hline Fort Hamilton High School & 4.0 & 6.0 & 5.0 \\
\hline Juan Morel Campos Secondary School & 3.0 & 5.0 & 5.0 \\
\hline \multicolumn{4}{|l|}{ Manhattan } \\
\hline Choir Academy of Harlem & 5.0 & 5.0 & 0.0 \\
\hline F.H. LaGuardia High School of Music & 0.0 & 0.0 & 0.0 \\
\hline Professional Performing Arts High School & 0.0 & 0.0 & 0.0 \\
\hline Talent Unlimited High School & 0.0 & 0.0 & 1.0 \\
\hline Wadleigh Secondary School for the Performing Arts & 1.0 & 3.0 & 8.0 \\
\hline Gramercy Arts High School & 4.0 & 2.0 & 2.0 \\
\hline \multicolumn{4}{|l|}{ Queens } \\
\hline Bayside High School & 3.0 & 2.0 & 2.0 \\
\hline Forest Hills High School & 3.0 & 1.0 & 3.0 \\
\hline Frank Sinatra School of the Arts High School & $\mathrm{N} / \mathrm{A}$ & 0.0 & 0.0 \\
\hline Humanities and Arts Magnet High School & 1.0 & 2.0 & 2.0 \\
\hline \multicolumn{4}{|l|}{ Staten Island } \\
\hline Susan E. Wagner High School & 3.0 & 3.0 & 2.0 \\
\hline
\end{tabular}

Table 7. Dropout Rates-Celia Cruz, Bronx, and New York City Public Schools 20092011

\begin{tabular}{|l|c|c|c|}
\cline { 2 - 4 } \multicolumn{1}{c|}{} & $\mathbf{2 0 0 9}$ & $\mathbf{2 0 1 0}$ & $\mathbf{2 0 1 1}$ \\
\hline Celia Cruz & $2.7 \%$ & $2.7 \%$ & $2.7 \%$ \\
\hline Bronx Borough & $14.1 \%$ & $15.4 \%$ & $15.8 \%$ \\
\hline New York City & $11.8 \%$ & $12.1 \%$ & $12.3 \%$ \\
\hline
\end{tabular}

\section{Discussion and Implications}

Celia Cruz High School, a musically focused high school, was created for the purpose of allowing students to realize their artistic and academic potential. The 
musical and artistic nature of the school is the primary focus of the institution which may in and of itself enrich the lives of the students it serves. Music educators and arts education advocates may agree that arts education should be important in its own right. Decision-makers such as superintendents and politicians may be swayed by other arguments. It is clear that the Trump and Obama administrations' education agenda are focused on STEM and the Common Core Standards that appears to omit the arts. However, President Obama had stated in that he wanted Americans to remain creative and innovative ${ }^{21}$. The educational initiatives under the current administration are designed to generate better-prepared graduates for the workforce and college. A complete education, which is inclusive of the arts and music education, may actually spur creativity and innovation. Additionally, arts education as a part of the school curriculum may have the potential to encourage some of the nation's most disadvantaged youth to remain in school and ultimately earn a high school diploma. Educators in both arts and academically-focused schools can and should make the argument that the arts may be beneficial for students who may be disenfranchised.

Given the tie between graduation and state testing, this study reaffirmed prior research that focused exclusively on testing, even though testing per se was not examined here. For example, Johnson and Memmott ${ }^{22}$ examined the standardized test scores of music students in middle schools from the South, East Coast, Midwest, and West Coast of the United States. $(n=1,119)$ who participated in programs of differing quality. The middle school data indicated that for both English and math, students in both exceptional music programs and deficient instrumental programs scored better than those in non-music classes or deficient choral programs; however, the sample sizes were not large. Similarly, the 1999 Champions of Change study examining performance on standardized tests taken by low socioeconomic urban public-school students enrolled in the Chicago Arts Partnerships in Education (CAPE) found that 8 out of 12 high schools showed CAPE schools increasing their lead in math scores and 7 out of 12 showed CAPE schools increasing their lead. Although this study did not specifically focus on standardized test scores but rather on graduation rates, given that graduation rates are tied to standardized tests for math and reading, there is an apparent relationship between these studies and the consistently high graduation rate found when comparing Celia Cruz students against borough or city averages.

21. Barack H Obama, "State of the Union Address," (January 25, 2011)

22. Christopher M Johnson and Jenny E Memmott, "Examination of Relationships between Participation in School Music Programs of Differing Quality and Standardized Test Results," Journal of Research in Music Education 54, no. 4 (December 1, 2006): 293-307, https://doi.org/10.1177/002242940605400403. 
The dropout rates of Celia Cruz students were consistently lower than the New York City and the Bronx borough averages. Dropout rates in New York City and the borough of the Bronx consistently were in the double digits while the graduation rates of Celia Cruz remained consistently at $2.7 \%$ for a threeyear period. Given the economic realities of the Bronx and New York City, it is clear that Celia Cruz students are able to complete their high school education and earn high school diplomas at a much higher rate than the average students in the Bronx or New York City. The lower dropout rate may also be linked to the higher graduation rates of Celia Cruz high school that were most similar to most arts-focused schools in New York City and the Bronx. The dropout rate difference compared to the city and the borough may be an indication that Celia Cruz is advancing the educational outcomes of at-risk students, which is part of its mission (Rodriguez, p. 117) and which coincides with other studies of arts programs advancing the educational outcomes of students ${ }^{23}$. The consistently low dropout rate of Celia Cruz and other artsfocused schools compared to the city may be attributed to multiple factors, including having better resources. Nonetheless, compared to similar schools, counterparts, and the city at large that include areas that are socioeconomically more affluent than Celia Cruz, this school had a low dropout rate. Perhaps, in the context of a public school that may not be focused on the arts, music/arts educators may notice these same trends in their schools and may be able to make the case for their programs.

The apparently high graduation rates and low dropout rates that Celia Cruz and similar schools of the arts suggest that schools with an arts focus in the New York City Public School system are performing better than the average school in the district in terms of academic achievement. This study addressed the performance of schools of the arts and focused on the Celia Cruz High School of Music. However, the study may have implications for arts programs within the context of public schools that are not arts-focused. Earlier research suggested that students enrolled in arts programs within their schools might be academically more successful than the average student in their school. ${ }^{24}$ Given the plight and struggles of large urban school districts, students that participate in arts programs appear to persevere and eventually graduate from high school at a higher rate. School administrators, politicians, and educators should consider these findings and similar findings when determining the relevance of the arts within the curriculum. In urban settings where funding may be scarce, it is especially important to consider these

23. Sharon Davis Gratto, "Arts Education in Alternative School Formats," Arts Education Policy Review 103, no. 5 (2002): 17-24, https://doi.org/10.1080/10632910209600300.

24. Sandra Ruppert, "Critical Evidence: How the Arts Benefit Student Achievement," Critical Evidence: How the Arts Benefit Student Achievement (National Assembly of State Arts Agencies, 2006), https://bit.ly/2BirxsY. 
findings as well as similar findings when determining the place of the arts in these districts.

The limitation of this investigation is its narrow focus on a small school of music. Given the narrow focus of this investigation, it is impossible to generalize any of these facts to any other setting. The data presented in this document is not comprehensive and does not give a comprehensive picture of Celia Cruz High School nor does the data present comprehensive statistical analysis beyond the data provided by the New York Department of Education. However, some of the data presented demonstrated the arts-focused school outperforming the city and borough averages. Given that this data only presented music within the context of a performing arts school, further research should be done in similar schools with music programs that are not arts-focused or specialized. If music education and arts education programs can consistently show a relationship between (high) graduation rates and (low) dropout rates, arts educators and advocates may be able to make a strong argument that may speak volumes to lawmakers and school administrators alike. Similar investigations should be careful to avoid making claims that attempt to prove that music or the arts is the primary factor or that music or the arts makes one smarter. This study merely states that the arts could be the factor for some students in terms of motivation and the perseverance that it is required to complete a high school education, in particular for youth that may find themselves in challenging economic circumstances. Educators, whether they are in arts schools or comprehensive high schools, should make the argument for the arts especially if they are teaching in socioeconomically diverse communities.

\section{Conclusions}

The data in this investigation is only one case in a socioeconomically challenged area in New York City during 2007-2011. However, the statistical data (obtained by the New York City Department of Education) clearly show a pattern of success in comparison to similar schools. Similar programs around the world have appeared to be successful such as El Sistema (founded in 1975) which originated in impoverished areas of Venezuela (similar models exist around the world now). Maestro Gustavo Dudamel is perhaps one of its most accomplished alumni and has supported similar programs in the United States. It appears that including the arts in socioeconomically challenged areas even in less developed countries have yielded some success.

The data presented in this investigation focused on Celia Cruz High School and its success. However, if one looks at the data closely, Fordham School of the Bronx, also outperformed the borough average during the same period. The average graduation rates were higher and dropout rates lower 
than the borough average and New York City average. Other data that compare similar arts schools in New York in other boroughs had similar success rates. One of the most notable schools, and perhaps famous school of the arts that had an exceptional graduation rate (above 95\% from 2009-2011) and virtually no dropouts during this same period was the Fiorella LaGuardia School of the Arts.

Although one cannot draw a correlation to studying music or the arts to academic achievement, the data from this investigation and anecdotal data suggest that arts education can be a positive force for underprivileged youth. One cannot and should not conclude that music or the arts increases one's intelligence outside of its own sphere. However, competence in the arts may be a motivating factor that allows youth with limited economic means to complete their education and even thrive in their educational endeavors.

Societies around the world invest in education in some form to ensure that the members of their communities can be productive and contribute to a given society. Arts education may be a vehicle for individuals to find success and contribute to society even if they pursue other endeavors outside of the arts. In the United States, STEM education is one of the areas that both major political parties can agree on. However, an emphasis on STEM without regard for arts education is myopic and fails to consider the benefits of arts education throughout the socioeconomic spectrum. If arts education programs are eliminated, it may create an unintended obstacle for social mobility in underprivileged communities that are already lacking in resources.

Arts and arts education are valuable in and of themselves; they are a defining characteristic of civilization and societies throughout history. However, politicians and civic leaders may need to demonstrate their value beyond its own intrinsic worth to their constituencies. When resources are scarce in a community making the case for arts education may be challenging. Success stories in at-risk communities that have provided arts education for youth are not limited to Celia Cruz High School or the developed world. World leaders and local leaders should consider the value of these programs in their civic planning. There is evidence to suggest that the arts can enhance the lives of individuals and society.

\section{Bibliography}

Abeles, Harold, Judith Burton, and Robert Horowitz. "Champion Report: Learning in and Through the Arts: Curriculum Implications." Rep. Champion Report: Learning in and Through the Arts: Curriculum Implications. New York, NY: Teachers College, 1999.

Abril, Carlos R., and Brent M. Gault. "The State of Music in the Elementary School: The Principal's Perspective." Journal of Research in Music Education 54, no. 1 (2006): 6. https://doi.org/10.2307/3653452. 
Adderley, Cecil, Mary Kennedy, and William Berz. "'A Home Away from Home': The World of the High School Music Classroom." Journal of Research in Music Education 51, no. 3 (October 1, 2003): 190-205. https://doi.org/10.2307/3345373.

Broadcast. State of the Union Address. Washington, D.C., January 25, 2011.

Brown, Eleanor D., Barbara Benedett, and M. Elizabeth Armistead. "Arts Enrichment and School Readiness for Children at Risk." Early Childhood Research Quarterly 25, no. 1 (October 31, 2010): 112-24. https://doi.org/10.1016/j.ecresq.2009.07.008.

Cross, Beverly E. "Urban School Achievement Gap as a Metaphor to Conceal U.S. Apartheid Education." Theory Into Practice 46, no. 3 (2007): 247-55. https://doi.org/10. 1080/00405840701402299.

Dawood, Diane C. "College Readiness and Academic Success for Arts Magnet and Traditional High School Graduates ." Dissertation, UNF, 2009.

Freer, Patrick K. "Boys' Descriptions of Their Experiences in Choral Music." Research Studies in Music Education 31, no. 2 (December 1, 2009): 142-60. https://doi.org/10.11 77/1321103x09344382.

Gratto, Sharon Davis. "Arts Education in Alternative School Formats." Arts Education Policy Review 103, no. 5 (2002): 17-24. https://doi.org/10.1080/10632910209600300.

Gullatt, David E. "Research Links the Arts with Student Academic Gains." The Educational Forum 71, no. 3 (2007): 211-20. https://doi.org/10.1080/00131720709335006.

Johnson, Christopher M., and Jenny E. Memmott. “Examination of Relationships between Participation in School Music Programs of Differing Quality and Standardized Test Results." Journal of Research in Music Education 54, no. 4 (December 1, 2006): 293-307. https://doi.org/10.1177/002242940605400403.

Kemple, James J, Corrine Herlihy, and Thomas J Smith. "Making Progress Towards Graduation: Evidence from the Talent Development High School Model." Making Progress towards Graduation: Evidence from the Talent Development High School Model. Manpower Demonstration Research Corporation, May 1, 2005. https://www. mdrc.org/publication/making-progress-toward-graduation.

McGlone, Peggy. "For Third Year in a Row, Trump's Budget Plan Eliminates Arts, Public TV and Library Funding." Washington Post, March 18, 2019. https://www.washingtonpost. com/lifestyle/style/for-third-year-in-a-row-trumps-budget-plan-eliminates-arts-publictv-and-library-funding/2019/03/18/e946db9a-49a2-11e9-9663-00ac73f49662_sto ry.html.

Moore, Simon. "What Key Recession Indicators Are Telling Us Today." Forbes Forbes Magazine, August 20, 2019, https://bit.ly/2YMnGMH.

Oreck, Barry, Susan Baum, and Heather McCartney. "Champions of Change: The Impact of the Arts on Learning." Rep. Champions of Change: The Impact of the Arts on Learning. National Research Center on the Gifted and Talented, 1999. https://files.eric.ed.gov/ fulltext/ED435581.pdf.

Rodriguez, William. "Creating a School of Music: a Bronx New Century High School Initiative." Dissertation, Teachers College Press, 2003.

Rohner, James. "Rally the Troops." The Instrumentalist, 2010.

Ruppert, Sandra. "Critical Evidence: How the Arts Benefit Student Achievement." Critical Evidence: How the Arts Benefit Student Achievement. National Assembly of State Arts Agencies, 2006. http://www.nasaa-arts.org/Research/Key-Topics/Arts-Education/ critical-evidence.pdf.

“U.S. Census Bureau Quick Facts: Bronx County (Bronx Borough) New York.” Rep. U.S. Census Bureau Quick Facts: Bronx County (Bronx Borough) New York, n.d. 
"U.S. Census Bureau Quick Facts: United States." Rep. U.S. Census Bureau Quick Facts: United States, n.d.

White, Harvey. "White Paper: Steam Not Stem," n.d. 
